\title{
HORMONE RECEPTOR EXPRESSION AND RIBOCICLIB ACTIVITY IN HORMONE RECEPTOR POSITIVE, HUMAN EPIDERMAL GROWTH FACTOR RECEPTOR 2 NEGATIVE BREAST CANCER
}

\author{
EUGEN JAVOR ${ }^{1}$, LEJSA JAKUPOVIĆ ${ }^{2}$ AND MARKO SKELIN ${ }^{3}$ \\ ${ }^{1}$ Pharmacy Department, University Hospital for Tumors, Sestre milosrdnice University Hospital Center, \\ Zagreb, Croatia \\ ${ }^{2}$ Pharmacy Department, Sestre milosrdnice University Hospital Center, Zagreb, Croatia \\ 3Pharmacy Department, General Hospital Šibenik, Šibenik, Croatia
}

\begin{abstract}
Summary
In the randomized, placebo-controlled, phase 3 MONALESSA-2 trial, in patients with hormone receptor positive $(\mathrm{HR}+)$ [the estrogen receptor (ER) and/or progesterone receptor (PR)] and human epidermal growth factor 2 receptor negative (HER2-) advanced breast cancer (BC), progression-free survival (PFS) was significantly longer among those receiving ribociclib [cyclin-dependent kinases 4 and 6 (CDK4/6) inhibitor] plus letrozole compared to patients receiving placebo plus letrozole. Additionally, ER+/PR+ cohort demonstrated higher hazard ratio for PFS than ER+/PR- cohort (0.62 vs. 0.36). Evidence from cell-line models suggests that PR signaling is tightly linked to cell-cycle regulation in terms of inhibition of CDK $4 / 6$ activity when exposed to progestin. A possible explanation of this finding may be that high PR expression could interfere with ribociclib activity on the cyclin-kinase level. Furthermore, it is questionable whether PR level determines the efficacy of ribociclib administration with higher levels of this receptor being predictive of ribociclib inefficacy. Considering the safety profile of ribociclib, it's necessary to perform analysis of PFS among ER+/PR+ patients receiving ribociclib, to potentially assess the cut-off value of PR expression (or ER/PR ratio) as a predictive marker of CDK4/6 efficacy.
\end{abstract}

KEY WORDS: ribociclib, breast cancer, hormone receptor expression

\section{EKSPRESIJA HORMONSKIH RECEPTORA I AKTIVNOST RIBOCIKLIBA U KARCINOMOMU DOJKE S POZITIVNIM HORMONSKIM RECEPTORIMA I NEGATIVNIM RECEPTOROM ZA HUMANI EPIDERMALNI FAKTOR RASTA 2}

\section{Sažetak}

MONALESSA-2 je placebo kontrolirana randomizirana klinička studija faze 3 koja je uključila bolesnike s uznapredovalim karcinomom dojke s pozitivnim hormonskim receptorima (HR+) [estrogenski receptori (ER) i/ili progesteronski receptori (PR)] te negativnim receptorom za humani epidermalni faktor rasta 2 (eng. HER2-). Studija je pokazala kako je preživljenje bez progresije bolesti (eng. PFS) bilo značajno dulje u onih bolesnika koji su primali ribociklib [inhibitor ciklinovisne kinaze 4 i 6 (CDK4/6)] uz letrozol u usporedbi s pacijentima koji su primali placebo i letrozol. Međutim, ER+/PR+ grupa imala je viši omjer rizika (eng. hazard ratio) za preživljenje bez progresije bolesti (PFS) od ER+/PR- grupe (0.62 vs. 0.36). Dokazi iz modela staničnih linija sugeriraju kako je signalni put PR usko vezan za regulaciju staničnog ciklusa kod inhibicije aktivnosti CDK 4/6 nakon izlaganja progestinu. Moguće objašnjenje ovih saznanja može biti povezano s visokom ekspresijom PR koja interferira s aktivnošću ribocikliba na razine ciklin-kinaze. Stoga, upitno je da li razina ekspresije PR receptora utječe na učinkovitost primjene ribocikliba, tj. da li njegova veća ekspresija može uzrokovati smanjenje učinkovitosti ribocikliba. S obzirom na sigurnosni profil ribocikliba, potrebno je izvršiti analize PFS vrijednosti bolesnika koji prima- 
ju ribociklib ovisno o razinama ekspresije hormonskih receptora kako bi se potencijalno odredile vrijednosti ekspresije PR (ili ER/PR omjera) kao markera učinkovitosti inhibitora CDK4/6.

KLJUČNE RIJEČI: ribociklib, karcinom dojke, ekspresija hormonskih receptora

\section{INTRODUCTION}

Approximately $72 \%$ of all breast cancers (BC) are hormone receptor positive $(\mathrm{HR}+)$ [the estrogen receptor (ER) and/or progesterone receptor (PR)] and human epidermal growth factor receptor 2 negative (HER2-) (1). Single HR+/HER2- (ER+/PR-/ HER2- or ER-/PR+/HER2-) BC has poorer prognosis than double HR+/HER2- (ER+/PR+/HER2-) BC. There is also difference in prognosis between single $\mathrm{HR}+/ \mathrm{HER} 2-\mathrm{BC}$. It is proven that ER-/PR+/HER2has poorer disease free survival (DFS) and overall survival (OS) compared to ER+/PR-/HER2- BC (2). Thus we can conclude that both estrogen and progesterone have an effect on HR+ BC cells. Endocrine therapy is the backbone of $\mathrm{HR}+/ \mathrm{HER} 2-\mathrm{BC}$ treatment. In early $\mathrm{BC}$ the endocrine therapy is considered curative, while in advanced BC its role is to control tumor growth and preserve quality of life. As in all advanced cancers, resistance to current therapy eventually develops, so there is constant need for alternative regiments that can overcome or at least delay resistance. One of these alternative regiments in advanced $B C$ is combination of ribociclib [selective cyclin-dependent kinases 4 and 6 (CDK4/6) inhibitor] and letrozole (aromatase inhibitor). Ribociclib plus letrozole was compared to placebo plus letrozole in Mammary Oncology Assessment of LEE011's (Ribociclib's) Efficacy and Safety (MONALEESA-2) randomized, placebocontrolled, phase 3 trial (3). This combination was evaluated in postmenopausal woman with $\mathrm{HR}+$ / HER2- recurrent or metastatic BC who had not received any systemic therapy for advanced disease. Ribociclib plus letrozole was proven to be superior to letrozole alone in term of progression-free survival (PFS) [hazard ratio, 0.56 ; 95\% confidence interval (CI), 0.43 to 0.72 ; $\mathrm{P}=3.29 \times 10^{-6}$ for superiority] which was primary endpoint of the trial.

\section{Different efficacy between the subgroups in the MONALESSA-2 trial}

In the MONALESSA-2 trial, ribociclib was given orally $600 \mathrm{mg}$ per day on a 3-weeks-on, 1-week-off schedule together with letrozole orally
Table 1.

\section{CHARACTERISTICS OF THE PATIENTS AT BASELINE} REGARDING HR EXPRESSION

\begin{tabular}{|c|c|c|c|c|}
\hline Groups & $\begin{array}{c}\text { ER+, no. } \\
(\%)\end{array}$ & $\begin{array}{c}\text { ER-, no. } \\
(\%)\end{array}$ & $\begin{array}{c}\text { PR+, no. } \\
(\%)\end{array}$ & $\begin{array}{c}\text { PR-, no. } \\
(\%)\end{array}$ \\
\hline $\begin{array}{c}\text { Ribociclib } \\
(\mathrm{N}=334)\end{array}$ & $332(99.4)$ & $2(0.6)$ & $271(81.1)$ & $63(18.9)$ \\
\hline $\begin{array}{c}\text { Placebo (N) } \\
=334)\end{array}$ & $333(99.7)$ & $1(0.3)$ & $278(83.2)$ & $56(16.8)$ \\
\hline
\end{tabular}

* Hormone receptor-HR, Estrogen receptor-ER, Progesterone receptor-PR

Table 2.

SUBGROUP ANALYSIS OF PFS REGARDING HR EXPRESSION

\begin{tabular}{|c|c|c|}
\hline $\begin{array}{c}\text { Ribociclib vs. } \\
\text { Placebo for } \\
\text { PFS }\end{array}$ & $\begin{array}{c}\text { ER+/PR+, hazard } \\
\text { ratio }(95 \% \mathrm{Cl})\end{array}$ & $\begin{array}{c}\text { ER+/PR-, hazard } \\
\text { ratio }(95 \% \mathrm{Cl})\end{array}$ \\
\cline { 2 - 3 } & $0.62(0.46-0.82)$ & $0.36(0.20-0.65)$ \\
\hline
\end{tabular}

* Hormone receptor-HR, Progression-free Survival-PFS, , Estrogen receptor-ER, Progesterone receptor-PR, , Confidence interval-CI

$2.5 \mathrm{mg}$ per day, until progression. Previous adjuvant and neoadjuvant therapy with a nonsteroidal aromatase inhibitor was allowed only if diseasefree interval was more than 12 months. Looking at basic characteristics of included population, ER+ was present in almost all patients in the trial (99.4\% in ribociclib and $99.7 \%$ in placebo group), while PR+ something less $(81.1 \%$ in ribociclib and $83.2 \%$ in placebo group) (Table 1 ). In the subgroup analysis different pattern of clinical efficacy occurred. ER+/PR+ cohort demonstrated higher hazard ratio for PFS than combined ER+/PR- and ER-/ PR+ cohort, 0.62 vs. 0.36 , respectively (Table 2) (3). Since ER is positive in $\sim 100 \%$ of patients, other subgroup included mostly ER+/PR-/HER2- while number of ER-/PR+/HER2- BCs is negligible. Therefore ribociclib could be more effective in the ER+/PR- than ER+/PR+ cohort. Possible explanation for different efficacy between the cohorts may be that high PR expression could interfere with ribociclib activity on cyclin-kinase level.

\section{PR expression and cyclin-kinase activity}

Progestins cause inhibition of cellular proliferation in T-47D BC cells, which is preceded by 
decreased cyclin abundance and G1 cyclin-dependent kinase (CDK) activities (4). G1 CKDs are cyclin D-CDK4/6 and cyclin E-CDK2, whose activity is governed by changes in cyclin abundance and interactions with CDK inhibitors. CKD inhibitors from INK4 family form complexes with CDK4 and CDK6. Swarbrick and colleagues demonstrated in vitro that progestin treatment causes higher expression of CDK4/6 inhibitors, and inhibition of cellular proliferation in BC cells follows (4). Dysregulated cyclin DCDK4/6-INK4-retinoblastoma ( $\mathrm{Rb})$ pathway is frequently observed in cancer and could result in tumor progression (5). Cyclin D1, which is encoded by CCND1 gene, regulates ER $\alpha$ transactivation (6) and since CDK4/6 overexpression and CCND1 amplification is often seen in $\mathrm{HR}+\mathrm{BC}(7)$, CDK4/6 inhibitors became a therapeutic option for advanced HR+/HER2- disease.

\section{Letrozole use and progesterone level}

Recently interesting finding was reported by Alviggi and associates regarding letrozole use and progesterone level in mid-luteal phase in three young BC patients undergoing controlled ovarian stimulation (COS) [8]. Very high progesterone values (mean $186.6 \pm 43.6 \mathrm{ng} / \mathrm{mL}$ ) were detected in these small case series, which are probably related with the use of letrozole independently of the most commonly used trigger regimen [human chorionic gonadotropin (hCG) or $\mathrm{GnRH}$ agonist (GnRH-a)]. Authors suggest that letrozole and consequently inhibition of the estrogen-negative feedback on hypothalamuspituitary axis can cause low estrogen level in luteal phase (8). There is difference in the dosing of letrozole in COS and HR+ BC treatment $(5 \mathrm{mg} /$ day and $2.5 \mathrm{mg} /$ day) that can possibly contribute to somewhat higher progesterone level. However, we do not consider that this double dose of letrozole in COS can contribute in that extent to such a huge difference in progesterone level. In other observational trial with $21 \mathrm{BC}$ patients who underwent COS with letrozole, progesterone levels did not differ significantly $(\mathrm{P}=0.092)$ in contrast to group of 21 infertile patients who underwent COS [9]. However, almost half of the population in the study group received $\mathrm{GnRH}$ antagonist, which could bias the results regarding progesterone level (9).

\section{Population that can have the most benefit from CDK4/6 inhibitor treatment}

In the era of various new small molecules and monoclonal antibodies, subpopulation analysis should be conducted to determine which subpopulation will have benefit from this kind of treatment and which not. It is common that new antineoplastic drugs are quite toxic for patients, and also toxic financially for health care insurances. When ribociclib was compared to placebo group, it has reported a higher incidence of any adverse event, especially those of Grade 3 and Grade 4 (3). Thus it is quite important, besides pharmacoeconomic analysis, to determine which patients are the most suitable for ribociclib administration.

Connecting in vitro findings with findings from the clinical trials of ribociclib we can noticed several interesting findings. Since letrozole caused higher progesterone levels in mid-luteal phase we can assume that this progesterone can bind to ER+/PR+/HER2- BC cells and cause higher expression of CDK4/6 inhibitors and consequently compete with ribociclib activity. Since ribociclib demonstrated more superior in ER+/PR- than ER+/PR+ cohort it would be necessary to perform analysis of PFS among ER+/PR+ cohort in order to potentially assess the cut-off value of PR expression (or ER/PR ratio) as a predictive marker of CDK4/6 inhibitor efficacy. Amplification of CCND1 gene, which regulates ER $\alpha$ transactivation, is often seen in $\mathrm{HR}+\mathrm{BC}$. Thus we can assume that CDK4/6 inhibitor would be efficient in BC cells that have ER+ expression, but not in those that have only PR+ expression. Looking at the results of the MONALESSA-2 trial we come out with a conclusion that ribociclib has not proven its efficacy in the ER-/PR+/ HER2- cohort. ER+ was present in $99.4 \%$ and $99.7 \%$ of patients in ribociclib and placebo groups, thus in the ER-/PR+/HER2- cohort was only 2 patients in ribociclib and 1 in placebo group (3).

Intrinsic luminal subtype is also strong prognostic factor in BC. Luminal B BC has a poorer prognosis than Luminal A BC [10], In the MONALESSA-2 trial there was no subpopulation analysis regarding Luminal type $\mathrm{BC}$, which could also possibly reveal the more rational use of the CDK4/6 inhibitors.

If we look for the incidence of HR+/HER2- BC subtypes among all BC population, it is $59 \%, 4.5 \%$, 
and $0.9 \%$ for ER+/PR+/HER2-, ER+/PR-/HER2-, and ER-/PR+/HER2-, respectively [2]. Therefore it is quite a large population that can be candidates for ribociclib therapy if they develop advanced disease.

\section{CONCLUSION}

Due to safety and pharmacoeconomic consideration, ribociclib plus letrozole should be given in the advanced HR+/HER2- BC: in the ER+/ $\mathrm{PR}-$ cohort and in ER+/PR+ cohort. However, the cut-off value of PR expression (or ER/PR ratio) in the ER+/PR+ cohort should be conducted first, to determine CDK4/6 inhibitor efficacy regarding PR expression. Currently, there is no evidence that ribociclib plus letrozole should be used in ER-/PR+/ HER2- BC.

\section{REFERENCES}

1. Howlader N, Altekruse S, Li C, Chen V, Clarke C, Ries $\mathrm{L}$, et al. US Incidence of Breast Cancer Subtypes Defined by Joint Hormone Receptor and HER2 Status. JNCI: Journal of the National Cancer Institute. 2014;106(5); doi: 10.1093/jnci/dju055.

2. Bae SY, Kim S, Lee JH, et al. Poor prognosis of single hormone receptor- positive breast cancer: similar outcome as triple-negative breast cancer. BMC Cancer. 2015;15:138; doi: 10.1186/s12885-015-1121-4.
3. Hortobagyi GN, Stemmer SM, Burris HA, et al. Ribociclib as First-Line Therapy for HR-Positive, Advanced Breast Cancer. N Engl J Med 2016;375:1738-48.

4. Swarbrick A, Lee CSL, Sutherland RL, Musgrove EA. Cooperation of p27/kip and p18/INK4c in progestinmediated cell cycle arrest in T-47D breast cancer cells. Mol Cell Biol. 2000;20:2581-91.

5. Hamilton E, Infante JR. Targeting CDK4/6 in patients with cancer. Cancer Treat Rev. 2016;45:129-38.

6. Casimiro MC, Wang C, Li Z, et al. Cyclin D1 determines estrogen signaling in the mammary gland in vivo. Mol Endocrinol. 2013;27(9):1415-28.

7. Comprehensive molecular portraits of human breast tumours. Nature. 2012;490(7418):61-70.

8. Alviggi C, Marci R, Vallone R, et al. High progesterone levels during the luteal phase related to the use of an aromatase inhibitor in breast cancer patients. Eur Rev Med Pharmacol Sci. 2017;21(13):3134-38.

9. Goldrat O, Gervy C, Englert Y, Delbaere A, Demeestere I. Progesterone levels in letrozole associated controlled ovarian stimulation for fertility preservation in breast cancer patients. Hum Reprod. 2015;30(9):2184-9.

10. Ades F, Zardavas D, Bozovic-Spasojevic I, et al. Luminal B breast cancer: molecular characterization, clinical management, and future perspectives. J Clin Oncol. 2014;32(25):2794-803.

Corresponding author: Marko Skelin, Pharmacy Department, General Hospital Šibenik, Stjepana Radića 83, 22000 Šibenik, Croatia.e-mail: markoskelin@yahoo.com 